\title{
Glaciar Upsala, Patagonia: rapid calving retreat in fresh water
}

\author{
Charles R. Warren, "Debbie R. Greene, \\ Department of Geography, University of Edinburgh, Drummond Street, Edinburgh EH8 9XP, Scotland \\ NeIL F. GLASSER \\ English Nature, Northminster House, Peterborough PE1 1UA, England
}

\begin{abstract}
The calving rates and calving styles of temperate glaciers that calve into fresh water are distinctively different from those of temperate tide-water glaciers. These contrasts are important for interpreting and predicting the response of ice masses to climate change. Glaciar Upsala is a large calving outlet of Hielo Patagónico Sur (southern Patagonia ice field). Its twentieth-century retreat has been climate-driven but significantly modulated by calving dynamics and by the transition from melting to calving at its eastern terminus. Here, the onset of rapid calving in the early $1980 \mathrm{~s}$ initiated retreat at $\leq 440 \mathrm{~m} \mathrm{a}^{-1}$. The $1992-93$ calving rate $\left(v_{c}\right)$ is estimated to be $60 \mathrm{~m} \mathrm{a}^{-1}$ in a mean water depth $\left(h_{\mathrm{w}}\right)$ of $67 \mathrm{~m}$. A $v_{\mathrm{c}} / h_{\mathrm{w}}$ relationship for fresh water based on 14 sites around the world, including seven deep-water sites, confirms both the linear dependency of $v_{\mathrm{c}}$ on $h_{\mathrm{w}}$ and the contrast between calving rates in tide water and fresh water. As yet, no physical explanation for this contrast exists, but differences in subaqueous melt rates, longitudinal strain rates and crevassing may provide a partial explanation.
\end{abstract}

\section{CALVING RATES IN FRESH WATER}

Calving remains one of the least understood glaciological processes. Calving glaciers are sensitive to trough geometry, and because of the instability of calving termini they can fluctuate independently of climate (Meier and Post, 1987; Warren, 1991, 1992). Calving rates correlate strongly with both water depth and ice thickness at the terminus (Brown and others, 1982), but the physical nature of these relationships remains unclear Hughes, 1992; Meier, 1994). Temperate tide-water glaciers have been extensively studied, whereas fresh-water calving glaciers have received little attention despite the significance of fresh-water calving for glacio-climatic relationships today and in geological time Kirkbride, 1993; Warren, 1994). Interest in fresh-water calving was stimulated by hydro-power schemes in glacierized catchments (Laumann and Wold, 1992). Such studies revealed that, in any given water depth $\left(h_{\mathrm{w}}\right)$, calving rates $\left(v_{\mathrm{c}}\right)$ are about an order of magnitude less than those in tide water (Funk and Röthlisberger, 1989). The $v_{\mathrm{c}} / h_{\mathrm{w}}$ relationship for fresh water proposed by these authors was:

$$
v_{\mathrm{c}}\left[\mathrm{m} \mathrm{a}^{-1}\right]=1.9\left[\mathrm{a}^{-1}\right] h_{\mathrm{w}}+12\left[\mathrm{~m} \mathrm{a}^{-1}\right] .
$$

This was based on just six sites. At four of these, $h_{\mathrm{w}}$ was $\leq 20 \mathrm{~m}$, limiting the reliability of the relationship for predicting $v_{\mathrm{c}}$ in deeper water.

\footnotetext{
* Present address: Department of Geography, University of St Andrews, Purdie Building, North Haugh, St Andrews, Fife KY16 9ST, Scotland.
}

The need for an improved database of fresh-water calving rates prompted this work in Patagonia. The major eastern outlet glaciers of Hielo Patagónico Sur (southern Patagonia ice field) all calve into large, deep lakes (Warren and Sugden, 1993). In this study of the historic behaviour of Glaciar Upsala, we document the onset of rapid retreat following the initiation of rapid calving in a new proglacial lake. We also present a revised $v_{\mathrm{c}} / h_{\mathrm{w}}$ relationship for fresh water, combining new data from Patagonia with published information. At seven of the 14 sites $h_{\mathrm{w}}$ exceeds $50 \mathrm{~m}$.

\section{GLAGIAR UPSALA}

Glaciar Upsala $\left(49^{\circ} 50^{\prime} \mathrm{S}, 73^{\circ} 17^{\prime} \mathrm{W}\right)$ has a surface area of $870 \mathrm{~km}^{2}$ and a length of about $60 \mathrm{~km}$, making it one of the largest Southern Hemisphere glaciers outside Antarctica, and South America's longest (Aniya and Skvarca, 1992). 20th-century thinning has caused the terminus to divide into three distributaries (Fig. 1). The largest arm, Upsala west, terminates in Lago Argentino at a calving front $4 \mathrm{~km}$ wide and $60-80 \mathrm{~m}$ high. Ice velocities $4 \mathrm{~km}$ behind the calving front are $700 \mathrm{ma}^{-1}$, and the equilibrium-line altitude (ELA) is estimated to be $1150 \mathrm{~m}$, giving an accumulation-area ratio of 0.63 Aniya and Skvarca, 1992 ). Surface gradients in the terminal $20 \mathrm{~km}$ do not exceed $2.5^{\circ}$, but crevassing is intense, especially west of the medial moraines. Proglacial water depths are unknown. However, the great size and the tabular form of the icebergs suggest that water depths are considerable: icebergs with estimated volumes greater than $10^{6} \mathrm{~m}^{3}$ are common, some of them detaching without rolling over. Upsala central and east calve into Lago Guillermo, a lake formed by recent 


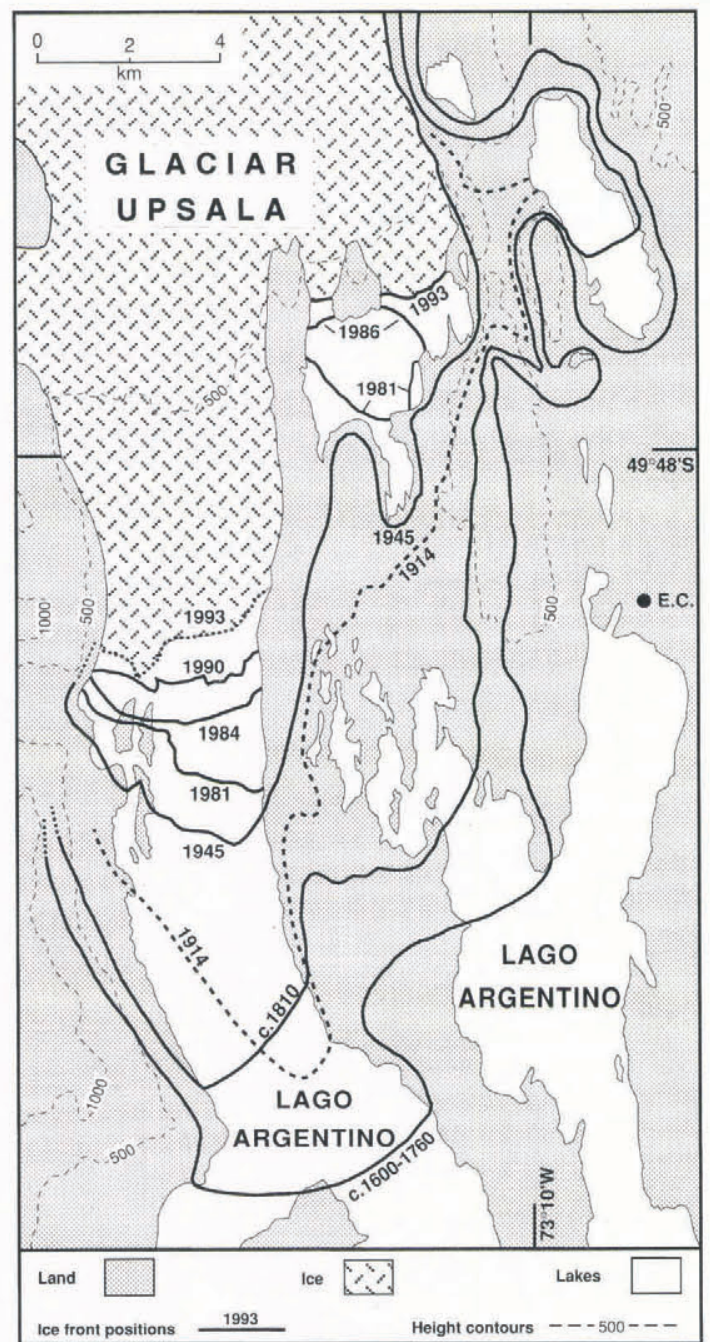

Fig. 1. Primary retreal slages of Glaciar Upsala since about 1600. Details of sources are given in the text. EC, Estancia Cristina.

glacier retreat (Fig. 2). Upsala central descends steeply to the lake, cut by regular crescentic crevasses, whereas Upsala east has a lower gradient and is less crevassed, with large areas of smooth ice within $2 \mathrm{~km}$ of the terminus. Calving activity is infrequent and small-scale relative to that at Upsala west. Meteorologically, the glacier terminus lies in the transition zone between mountain and pampas climates. The western margin of the glacier is wetter, cloudier and less windy than the east side, and the vegetation reflects this contrast (Mercer, 1965).

\section{METHODOLOGY}

The fluctuation history is derived from published sources Agostini, 1945; Mercer, 1965; Malagnino and Strelin, 1992 and remotely sensed data: aerial photographs from 1945, 1967, 1968, 1975 and 1981, and a LANDSAT image of 14 January 1986. The ice-front position of Upsala east in March 1992 and 1993 was fixed using a theodolite/EDM and a satellite-positioning system. An approximate icemargin position in 1914 was provided by $\mathrm{J}$. Masters whose family founded Estancia Cristina (Fig. 1) in that year.

Work at Upsala east was carried out in the late austral summers of 1992 and 1993. In March 1992 two markers

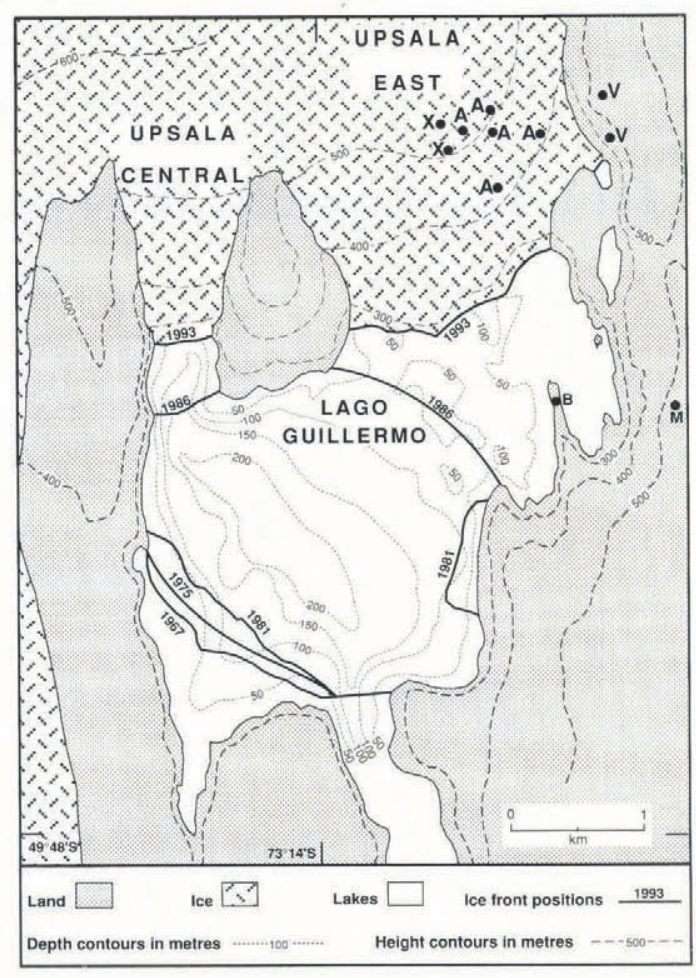

Fig. 2. Bathymetry of Lago Guillermo and ice-front positions of Upsala east during retreal through the lake. Contour interval is $50 \mathrm{~m}$ in the lake and $100 \mathrm{~m}$ elsewhere. Contours on the glacier and in areas deglaciated since 1981 have been estimated. $V$, ice-velocity survey points; X, velocity markers (1992); $B$, bathymetry survey point; $A$, ablation stakes; and M, meteorological station (1993).

were positioned close to the geometric centre line, and displacements measured during a $13 \mathrm{~d}$ period using a "total-station" Geodimeter theodolite/EDM and standard survey methods (Fig. 2). A network of five ablation stakes was monitored daily for 14 d in February and March 1993, and standard meteorological data were recorded concurrently (Fig. 2). To map the bathymetry of Lago Guillermo, 291 individual echo soundings were taken along 23 transects. In the eastern sector of the lake, locational accuracy was achieved using a theodolite/EDM; in the western sector, transects were chosen between prominent lake-shore features, rowing on still days to minimize drift. Ice-cliff heights were surveyed from the lake shore. Qualitative observations of the evolving nature of the calving front, and of the characteristics and frequency of calving, were recorded throughout both field seasons. Visual estimates of iceberg volumes incorporated waterdepth measurements near grounded bergs.

\section{RESULTS}

Glaciar Upsala has been retreating throughout historical time (Fig. 1). The neoglacial maximum and subsequent retreat positions are marked by pronounced vegetation trim-lines and moraines. The maximum was dated dendrochronologically by Mercer (1965) to the period $1600-1760 \mathrm{AD}$; rapid retreat $\left(\approx 120 \mathrm{~m} \mathrm{a}^{-1}\right)$ commenced in the early 19th century. By the beginning of the 20th 
century the glacier had reached a narrowing point, and it retreated more slowly $\left(\approx 50 \mathrm{~m} \mathrm{a}^{-1}\right)$ until the late $1960 \mathrm{~s}$. Between 1970 and 1978, a central part of Upsala west advanced about $400 \mathrm{~m}$ (Aniya and Skvarca, 1992). The eastern margin retained its position from 1931 until 1981, but then retreated at $800 \mathrm{ma}^{-1}$ until 1990. Between March 1992 and 1993 the eastern half of Upsala west retreated about $1000 \mathrm{~m}$. Retreat rates of Upsala east are given in Table 1. When observed in 1928 by Agostini (1945), the bedrock ridge now separating Upsala west and east was still under ice. By 1967 it had been exposed by thinning, and Lago Guillermo was beginning to form. Rapid retreat occurred throughout the 1980s.

Results of the ice-velocity measurements are given in Table 2. The annual velocities are simple extrapolations, not incorporating seasonal variability. No seasonal velocity data exist for any Patagonian glacier, so the error is unknown. Mean ablation rates ranged from 3.6 to $11.2 \mathrm{~cm}$ w.e. $\mathrm{a}^{-1}$ with a mean of $6.8 \mathrm{~cm}$ w.e. $\mathrm{a}^{-1}$. Melt-rate variations correlate significantly (at the 0.05 level) with variations in minimum daily temperature $\left(r_{\mathrm{s}}=0.64\right)$ and wind speed $\left(r_{\mathrm{s}}=0.60\right)$ but not with maximum temperature $\left(r_{\mathrm{s}}=-0.18\right)$, mean daily temperature $\left(r_{\mathrm{s}}=0.15\right)$ or sun hours $\left(r_{\mathrm{s}}=-0.4\right)$. On and around the glacier, wind speeds are frequently extreme, gusting to $40 \mathrm{~m} \mathrm{~s}^{-1}$ at times.

The bathymetry of Lago Guillermo is shown in Figure 2. About $100 \mathrm{~m}$ in front of Upsala east the mean depth ( $n=32$ ) is $65 \mathrm{~m}$, and there is no consistent shallowing or deepening trend towards the glacier. The average ice-cliff height is $34 \mathrm{~m}$ (range: $29-41 \mathrm{~m}$ ). Combining ice-cliff heights with the near-ice bathymetry, the maximum ice thickness at the calving front is estimated to be $150 \mathrm{~m}$ and the mean thickness $(n=15)$ to be $101 \mathrm{~m}$. Given a glacier width of $1600 \mathrm{~m}$ and a width-averaged ice velocity of about $60 \mathrm{ma}^{-1}$, the annual mass flux at the terminus of Upsala east is approximately $9.7 \times 10^{6} \mathrm{~m}^{3} \mathrm{a}^{-1}$ or $0.01 \mathrm{~km}^{3}$ $\mathrm{a}^{-1}$. Following Powell and Molnia (1989), mean annual calving speed $\left(v_{\mathrm{c}}\right)$ can be derived using the equation

$$
v_{\mathrm{r}}=v_{\mathrm{i}}-v_{\mathrm{c}}-v_{\mathrm{m}}
$$

where $v_{\mathrm{c}}$ is related to frontal change $\left(v_{\mathrm{r}}\left[\begin{array}{lll}1992 & 93\end{array}\right]=\right.$ $\left.-25 \mathrm{ma}^{-1}\right)$, ice velocity $\left(v_{\mathrm{i}}=60 \mathrm{ma}^{-1}\right)$ and ice melting $\left(v_{\mathrm{m}}\right)$ at the calving face. However, subaqueous melt rates at calving fronts are poorly known, and theoretical calculations yield values of uncertain validity (Warren and others, in press) so $v_{\mathrm{c}}$ was determined simply using

\section{Table 1. Upsala east: 20th-century retreat statistics}

\begin{tabular}{|c|c|c|c|c|c|}
\hline \multirow[t]{2}{*}{ Period } & \multicolumn{2}{|c|}{ Retreat } & \multicolumn{2}{|c|}{$\begin{array}{c}\text { Surface-area } \\
\text { loss }\end{array}$} & \multirow{2}{*}{$\begin{array}{c}\text { Mean water } \\
\text { depth } \\
\mathrm{m}\end{array}$} \\
\hline & $\mathrm{m}$ & $\left(\mathrm{ma}^{1}\right)$ & $\mathrm{km}^{2}$ & $\left(\mathrm{~km}^{2} \mathrm{a}^{-1}\right)$ & \\
\hline $1914 \quad 45$ & 1300 & $(42)$ & 10.0 & $(0.32)$ & 0 \\
\hline $1945 \quad 67$ & 2100 & (95) & 7.5 & $(0.34)$ & 50 \\
\hline $1967-75$ & 100 & (13) & 0.2 & $(0.03)$ & 65 \\
\hline 197581 & 130 & $(22)$ & 0.3 & $(0.04)$ & 75 \\
\hline $1981-86$ & 2200 & $(440)$ & 4.7 & $(0.94)$ & 140 \\
\hline 198692 & 1000 & $(167)$ & 2.2 & $(0.36)$ & 75 \\
\hline 199293 & $10-40$ & $(25)$ & 0.05 & $(0.05)$ & 65 \\
\hline
\end{tabular}

\begin{tabular}{|c|c|c|c|}
\hline Interval dates & $\begin{array}{l}\text { Total movement } \\
\mathrm{m}\end{array}$ & $\begin{array}{l}\text { Daily velocity } \\
\qquad \mathrm{m} \mathrm{d}^{-1}\end{array}$ & $\begin{array}{c}\text { Annual velocity } \\
\mathrm{m} \mathrm{a}^{-1}\end{array}$ \\
\hline \multicolumn{4}{|c|}{ Marker 1 (up-glacier) } \\
\hline $16-19$ & 0.836 & 0.300 & $(109)$ \\
\hline 19-23 & 1.000 & 0.244 & $(89)$ \\
\hline $23-29$ & 1.100 & 0.187 & $68)$ \\
\hline 1629 & 2.839 & 0.218 & $(80)$ \\
\hline \multicolumn{4}{|c|}{ Marker 2 (down-glacier) } \\
\hline $16-23$ & 1.860 & 0.272 & (99) \\
\hline $23-29$ & 1.260 & 0.214 & $(78)$ \\
\hline 1629 & 2.998 & 0.231 & $(84)$ \\
\hline
\end{tabular}

$$
v_{\mathrm{c}}=v_{\mathrm{i}}-v_{\mathrm{r}} .
$$

This yields a calving speed of $85 \mathrm{ma}^{-1}$. Given that $v_{\mathrm{m}}$ could be about $20-30 \mathrm{~m} \mathrm{a}^{-1}$, the true value of $v_{\mathrm{c}}$ could be $55-65 \mathrm{~m} \mathrm{a}^{-1}$.

At Upsala east the calving cliff is essentially vertical along its western half, but sections of the eastern half overhang at angles of $\leq 30^{\circ}$. Calving activity consists of high-magnitude/low-frequency events, producing prismatic icebergs which contrast with the large tabular bergs typical at Upsala west. Visual estimates of berg volumes suggest that most are in the range 1000 $50000 \mathrm{~m}^{3}$ with an upper limit of $500000 \mathrm{~m}^{3}$. Large bergs survive in Lago Guillermo for more than 2 weeks before breaking up and melting. Calving fluxes from Upsala east are probably about two orders of magnitude lower than those from Upsala west.

\section{DISCUSSION}

\section{Oscillations of Glaciar Upsala: climate and topography}

The only long-term regional climate data (1888-present) are from Punta Arenas on the Magellan Strait, $400 \mathrm{~km}$ distant, and may not reliably indicate the climate changes that affect the ice field (Warren and Sugden, 1993). Mean annual temperature and precipitation have fluctuated approximately in phase, peaking in the period $1930-50$ and around 1980. Temperatures fell by $1.2 \mathrm{C}$ between 1940 and 1969 , and then rose $0.7^{\circ} \mathrm{C}$ in the next 10 years. These trends could account for the advance of Upsala west in the early 1970s, the simultaneous cessation of retreat at $\mathrm{U}$ psala east and then the onset of rapid retreat at both termini during the 1980s.

However, while the retreat of Glaciar Upsala most probably has a climatic origin, reflecting a regional warming since the early 19th century, it has been modulated by topography and calving dynamics, as noted by Mercer (1965): topographic pinning points have determined still-stand locations and affected retreat rates. Detailed patterns and rates of fluctuation have been largely a product of the interaction between channel geometry and calving instabilities. For example, retreat rates of Upsala east during the 1980s (Fig. 2; Table 1) 
were clearly amplified by the increasing water depths $(<245 \mathrm{~m})$. If ice velocities were similar to those measured in 1992, calving rates between 1981 and 1986 were about $500 \mathrm{~m} \mathrm{a}^{-1}$, about nine times greater than at present.

\section{Characteristics of fresh-water calving}

Calving, whether into fresh or salt water, introduces inherent instability into the glacier system, but glaciers calving into fresh water appear to be more stable than tide-water glaciers. The magnitude/frequency distribution of icebergs produced in fresh water also differs from that in tide water. In both fresh water and tide water, mass losses through calving are often dominated by small numbers of large bergs. However, the profusion of small icebergs and brash ice so characteristic at active tide-water termini is typically absent from fresh-water fronts even when calving rates are high, indicating an even greater dominance by large events in fresh water. These characteristics of stability and iceberg production have been noted in Alaska (Qamar, 1988), Greenland (Warren, 1991), New Zealand (Kirkbride, 1993) and Patagonia (Warren, 1994).

The nature of calving at Glaciar Upsala is consistent with these observations. Periods with abundant brash ice are atypical at Upsala west and absent from Upsala east, and the iceberg flux at both termini appears to be dominated by large bergs. At Upsala east, retreat into Lago Guillermo produced a five-fold increase in the length of the calving front in increasing water depths. In tide water, this would probably trigger rapid retreat even if the mass balance were positive. However, 15 years of near-stability in deep water $\left(h_{\mathrm{w}} \leq 75 \mathrm{~m}\right)$ followed. If this still-stand was climatic in origin, it supports the suggestion that the climatic sensitivity of fresh-water glaciers is intermediate between that of non-calving and tide-water glaciers (Warren, 1991).

\section{Fresh-water calving rates}

Table 3 presents calving data for 14 temperate, grounded glaciers that calve in fresh water. Ideally, $v_{\mathrm{c}}$ should be calculated using Equation (2). Given the poor knowledge of $v_{\mathrm{m}}$ at calving fronts, however, Equation (3) was used. All three terms are in $\mathrm{m} \mathrm{a}^{-1}$ and averaged over the width of the glacier. The data in Table 3 are of variable quality. For the glaciers for which only centre-line ice velocities $\left(v_{\max }\right)$ are known, $v_{\mathrm{i}}$ was calculated by multiplying $v_{\max }$ by 0.73 . This empirical constant is derived from the temperate-tide-water glacier data set of Brown and others (1982) in which the relationship between $v_{\max }$ and $v_{\mathrm{i}}$ for 12 glaciers is remarkably consistent $(0.73 \pm 0.05)$. Values of $v_{\mathrm{i}}$ calculated in this way are underlined in Table 3 . For the Patagonian glaciers $(10-13)$, ice velocities were measured $1-5 \mathrm{~km}$ behind the calving front. The calving speeds given for glaciers 2 and 8 differ from those in the original sources because Laumann and Wold (1992) used $v_{\max }$ to calculate $v_{\mathrm{c}}$ while Goldthwait and others (1963) used a minimum ice velocity. At Glaciar Grey, $h_{\mathrm{w}}$ was measured by plumb-line soundings (personal communication from A. Mansilla, 1992), and at Glaciar Pio XI $h_{\mathrm{w}}$ has been estimated from maps drawn before and after the lake formed. Estimating $v_{\mathrm{r}}$ and $v_{\mathrm{c}}$ at Tasman Glacier,
New Zealand, is problematic because the terminus was evolving from a melting to a calving condition through a phase with complex terminus geometry (Kirkbride, 1989, $1993)$. Nevertheless, it is clear that $v_{\mathrm{c}}$ remained very low while $h_{\mathrm{w}}$ increased to a maximum of $130 \mathrm{~m}$. "Normal" calving commenced in 1991, producing small numbers of icebergs with volumes of several million cubic metres (Hochstein and others, in press).

Figure 3 presents $v_{\mathrm{c}} / h_{\mathrm{w}}$ relationships for fresh water based on the numerical values in Table 3 . The empirical data are expressed in the form

$$
\begin{aligned}
& v_{\mathrm{c}}=c h_{\mathrm{w}} \\
& v_{\mathrm{c}}=c h_{\max }
\end{aligned}
$$

in which $c$ is a calving coefficient. For $h_{\mathrm{w}}$ the best estimate of $c$ is $2.5 \pm 0.5$, and for $h_{\max }$ the best estimate of $c$ is $1.8 \pm 0.5$. This contrasts with a value of $c$ for temperate tide-water glaciers of $27.1 \pm 2$ (Brown and others, 1982).

The revised $v_{c} / h_{\mathrm{w}}$ relationship for fresh water confirms the robust but unexplained dependency of calving rate on water depth. This dependency is apparently linear. However, the data also allow the possibility that $v_{\mathrm{c}}$ increases non-linearly with $h_{\mathrm{w}}$. The suggestion of a nonlinear increase is more pronounced for the $v_{\mathrm{c}} / h_{\max }$ distribution (Fig. 3).

\section{Contrasting calving rates in tide and fresh water}

Figure 3 also confirms the existence of the great contrast between calving rates in tide water and fresh water. There is no overlap or continuum between the two relations. The important process contrasts must operate at or near the calving front, and various possible explanations are discussed below.

Meltwater buoyancy: While rates of ice loss by subaqueous melting are one to two orders of magnitude lower than those by calving (Syvitski, 1989), different melt rates in tide water and fresh water might affect calving rates. Funk and Röthlisberger (1989) noted that glacial meltwater is 200 times more buoyant in salt water than in fresh water, and thus suggested a strong dependence of calving rate on water density consequent upon differential rates of subaqueous melting. This requires a strong feedback from melting to calving and would indicate that melting at the calving front somehow significantly accelerates calving. This possibility is supported by the fact that at Columbia Glacier, Alaska, $v_{\mathrm{c}}$ and $v_{\mathrm{m}}$ both reach maxima in the autumn (Meier and others, 1985). Moreover, strong meltwater upwelling and thermal stratification of the proglacial water body are common at tide-water fronts (Powell and Molnia, 1989), whereas many proglacial lakes are thermally unstratified, with insignificant spatial and temporal variability in temperature, and no evidence of strong circulation. Such data exist for glaciers 3, 12 and 14 in Table 3 (Funk and Haeberli, 1990; Warren, 1994; Hochstein and others, in press). Warren and others (1995) suggest that subaqueous melt rates at tide-water termini may be significantly greater than hitherto thought. At present, then, this possibility remains strong.

Environmental factors: Contrasts between exposure to wind action, wave action (which carves notches at water level) 
Table 3. Fresh-water calving data for 14 grounded, temperate glaciers. $h_{\max }$, maximum water depth at the calving front; $h_{\mathrm{w}}$, width-averaged water depth; $v_{\max }$, centre-line surface ice velocily; $v_{\mathrm{i}}$, width-averaged surface ice velocity; $v_{\mathrm{r}}$, mean glacier retreat rate; and $v_{\mathrm{c}}$, calving rate. Melt rates at the calving face have not been incorporated. For furlher explanation and discussion, see text

\begin{tabular}{|c|c|c|c|c|c|c|c|}
\hline Glacier, location & Period & $\begin{array}{c}h_{\max } \\
\mathrm{m}\end{array}$ & $\begin{array}{c}h_{\mathrm{w}} \\
\mathrm{m}\end{array}$ & $\mathrm{ma}^{v_{\mathrm{i}}}$ & $\mathrm{ma}^{v_{\mathrm{r}}}$ & $\mathrm{ma}^{v_{\mathrm{c}}}$ & Source \\
\hline 1. Portage, Alaska & $1971-72$ & 160 & 110 & 165 & 50 & 215 & $\mathrm{a}$ \\
\hline 2. South Crillon, Alaska & $1933-61$ & 58 & 41 & 15.5 & -10 & 145 & b \\
\hline 3. Nordbo, Greenland & 197980 & 130 & 90 & 217 & -10 & 207 & a \\
\hline 4. Sabbione, Italy & $1961-73$ & 28 & 20 & 2 & 50 & 52 & a \\
\hline 5. Unteraar, Switzerland & $1932-45$ & 18 & 12 & 14 & 18 & 32 & a \\
\hline 6. Oberaar, Switzerland & $1953-67$ & 33 & 16 & 8 & 42 & 50 & a \\
\hline 7. Gries, Switzerland & $1968-79$ & 17 & 13 & 6 & 31 & 37 & a \\
\hline 8. Austdalsbreen, Norway & 196683 & 10 & 8 & $\underline{19}$ & 6 & 25 & c \\
\hline 9. Austdalsbreen, Norway & $1988-89$ & 33 & 25 & $\underline{26}$ & 75 & 101 & c \\
\hline 10. Grey, Chile & $1945 \quad 67$ & 250 & 165 & $\underline{3 \overline{30}}$ & 25 & 355 & $\mathrm{~d}, \mathrm{~g}$ \\
\hline 11. Pio XI north, Chile & $1945-76$ & 150 & 100 & $\overline{545}$ & -132 & 413 & $e, g$ \\
\hline 12. Moreno, Argentina & $1990-90$ & 220 & 175 & $\underline{510}$ & 0 & 510 & f \\
\hline 13. Upsala east, Argentina & 199292 & 119 & 67 & $\overline{60}$ & 25 & 85 & $\mathrm{~g}$ \\
\hline 14. Tasman, New Zealand & $1982-93$ & 130 & 78 & $\overline{2}$ & $<115$ & $<4$ & $\mathrm{~h}, \mathrm{i}$ \\
\hline
\end{tabular}

a. Funk and Röthlisberger, 1989

b. Goldthwait and others, 1963

c. Laumann and Wold, 1992 d. Lliboutry, 1956

e. Marangunić, 1964

f. Warren, 1994 g. This study

h. Hochstein and others, in press

i. Kirkbride, 1989. and tides might be expected to affect calving speeds. However, degree of exposure does not differ systematically between tide-water and fresh-water contexts. Wave action cannot be a necessary condition for fast calving because at Columbia Glacier the terminus has been protected from waves by dense brash ice during catastrophic calving retreat (Meier, 1994). Tidal action cannot explain more than a small part of the contrast unless it either greatly increases water circulation and heat advection to the ice front, or significantly weakens the calving front through the cyclical changes in stress regime.

Water chemistry: In rock, stress corrosion or chemical weakening of crack tips greatly increases rates of subcritical crack propagation. If the same holds true for ice this could be a contributory factor, but it has yet to be tested. However, calving rates at Glaciar San Rafael, Chile, exceed those predicted for tide water even though the salinity of the proglacial tidal lagoon is only half that of the open ocean (Warren and others, 1995). This argues against a water-chemistry explanation.

Over-steepening of the ice front: Calving termini tend towards overhang due to differential ice flow, undercutting at water level and subaqueous melting. Over-steepening of the front and forward bending, causing increasing tensile stress and shearing, may be important in promoting calving (Hughes, 1992; personal communication from R. LeB. Hooke, 1992). Lower rates of subaqueous melting in fresh water will work towards a reduction in oversteepening. Moreover, unfractured ice is stronger than crevassed ice and able to sustain greater amounts of overhang before reaching a critical fracture stress. This is borne out by considerable overhangs at Upsala east and Tasman Glacier.

Strain rates: Extending longitudinal strain rates may be systematically greater in tide-water glaciers. Accumulating longitudinal strains lead to crevassing (either actual or incipient) and stress weakening of the ice. There is an intimate link between crevasse density and $v_{\mathrm{c}}$ (Powell, 1980 , p. 36) simply because fractured ice is weaker than homogeneous ice: any process that promotes crevassing will in turn facilitate calving. A correlation between calving rates and near-terminus strain rates exists for Alaskan tidewater glaciers personal communication from R. LeB.

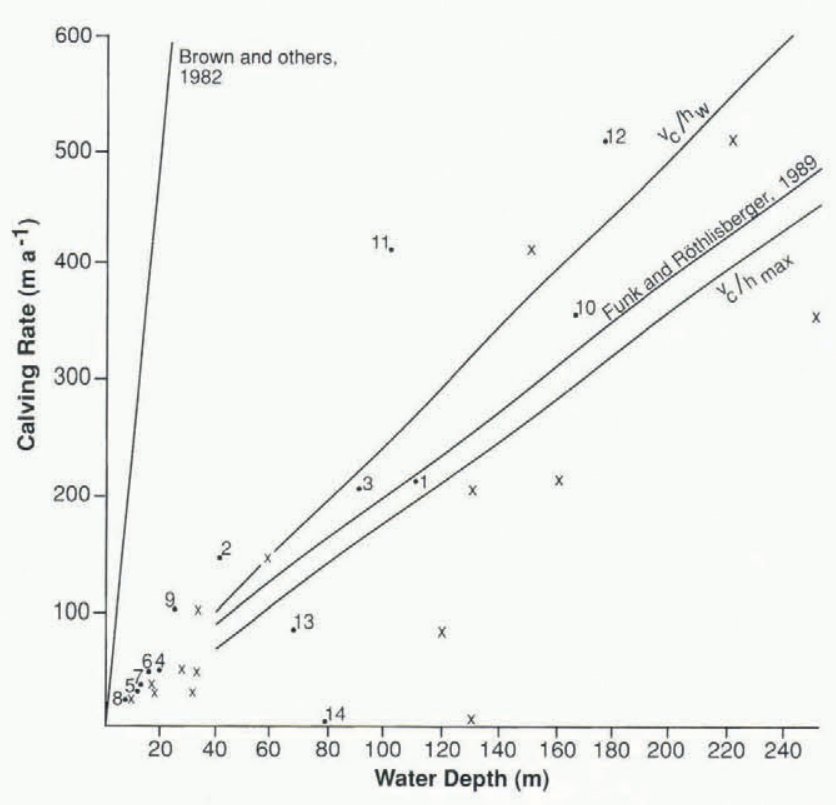

Fig. 3. The relationship between calving speed and water depth for 14 fresh-water glaciers, showing relationships for width-averaged water depth $\left(h_{\mathrm{w}}\right)$ (dala points shown as dots) and maximum water depth $\left(h_{\max }\right)$ (crosses). Data and sources are given in Table 3. Relationships proposed by Funk and Röthlisberger (1989), and by Brown and others (1982) for tide water, are also shown. 
Hooke, 1992). It is clear from the low $v_{c}$ in deep water at Tasman Glacier (Table 3 ) that deep water does not in itself produce rapid calving in fresh water. It is noteworthy that $v_{c}$ at glaciers 13 and 14 (Fig. 3), which have little and almost no crevassing, respectively, is considerably less than that predicted by Equations (4) and (5). Equally, glaciers 11 and 12 are profusely crevassed and calve at aboveaverage rates. It seems that deep water is a necessary but not a sufficient condition: intense crevassing is a sine qua non for rapid calving.

Synthesis: Why should fresh-water glaciers be systematically slower and less crevassed than tide-water glaciers, when in other respects (e.g. gradient, thickness, melt rates) they are indistinguishable? This raises the "chicken-and-egg", question of the relationship between $v_{\mathrm{c}}$ and $v_{\mathrm{i}}$. During catastrophic retreat at Columbia Glacier, both $v_{\mathrm{c}}$ and $v_{\mathrm{i}}$ have increased rapidly and in tandem (Meier, 1994), but it is not clear whether high $v_{\mathrm{c}}$ is a consequence or a cause of high $v_{\mathrm{i}}$. However, seasonal retreats correlated with accelerated $v_{\mathrm{i}}$ due to increasing effective slope and decreasing longitudinal effective stress (Meier and others, 1985), indicating that ice velocities may be driven by calving rates. If so, it raises the intriguing possibility that the depth and density of crevassing are greater at tidewater glaciers because high $v_{\mathrm{c}}$ produces higher $v_{\mathrm{i}}$ and longitudinal strain rates. Intense crevassing increases the glacier's surface area, in turn increasing melt-water production and promoting high velocities. Strong meltwater discharge at the terminus enhances water circulation and turbulent heat transfer.

This hypothetical sequence of process linkages acting in positive feed-back, combined with Funk and Röthlisberger's (1989) density-contrast hypothesis and frontal over-steepening, may explain why tide-water calving is so rapid and so much faster than fresh-water calving, and why tide-water glaciers commonly attain higher speeds than comparable fresh-water glaciers. It may also largely explain the contrasting calving styles: large bergs are more dominant in fresh water simply because of the lower crevasse density. The empirical and physical foundations on which this suggestion rests, however, remain narrow.

\section{CONGLUSION}

Fluctuations of Glaciar Upsala show that the influence of climate change on the position of a calving front is less significant in the short term than that of the transition from melting to calving, and than subsequent changes in calving rate. The relative importance of melting as against true mechanical calving, and the effect of the former on the latter, are important unknowns. Data relating to freshwater calving are still limited, while the physics of calving in fresh water and tide water, and the differences between the two, remain largely unknown. However, the strong dependence of calving rates on water depth in both tide water and fresh water is now beyond doubt.

\section{ACKNOWLEDGEMENTS}

The work was funded by a U.K. Natural Environment Research Council Fellowship to C.R.W. and NERC Grant
GR9/1199. N.F.G. and D.R.G. received grants from the Carnegie Trust and the Quaternary Research Association. Permission to work at Glaciar Upsala was granted by the Parque Nacional Los Glaciares. We wish to thank J. Masters at Estancia Cristina, and especially D. Feldman for all his cheerful assistance. Comments by M. Kirkbride, G. Casassa and an anonymous referee improved the manuscript.

\section{REFERENCES}

Agostini, A. M. de. 1945. Andes Patagónicos. Second edition. Buenos Aires, Guillermo Kraft.

Aniva, M. and P. Skvarca. 1992. Characteristics and variations of Upsala and Moreno glaciers, southern Patagonia. Bull. Glacier Res. 10, $39-53$.

Brown, C.S., M.F. Meier and A. Post. 1982. Calving speed of Alaska tidewater glaciers, with application to Columbia Glacier. U.S. Geol. Surv. Prof. Pap. 1258-C.

Funk, M. and W. Haeberli. 1990. Gletscher-Kalbungsgeschwindigkeit im Süsswasser: eine Studie am Nordbogletscher im Johan Dahl Land, SüdWest Grönland. Mitteilung VAW/ETHz, 20 8), 1-47.

Funk, M. and H. Röthlisberger. 1989. Forecasting the effects of a planned reservoir which will partially flood the tongue of Unteraargletscher in Switzerland. Ann. Glaciol., 13, 76-81.

Goldthwait, R. P., I. C. McKellar and C. Cronk. 1963. Fluctuations of Crillon Glacier system, southeast Alaska. Bull. IAHS, 8 1), 62 74.

Hochstein, M. P., D. Claridge, S. Henrys, A. Pyne, D. Nobes and S. F. Leary. In press. Downwasting of the Tasman Glacier (South Island, NZ): changes in the terminus region between 1971 and 1993. N.Z. J. Geol. Pliys.

Hughes, T.J. 1992. Theoretical calving rates from glaciers along ice walls grounded in water of variable depths. J. Glaciol., 38 (129), 282294.

Kirkbride, M.P. 1989. The influence of sediment budget on geomorphic activity of the Tasman Glacier, Mount Cook National Park, New Zealand. (Ph.D. thesis, University of Canterbury.)

Kirkbride, M. P. 1993. The temporal significance of transitions from melting to calving termini at glaciers in the central Southern Alps of New Zealand. Holocene, 3 3 , 232-240.

Laumann, T. and B. Wold. 1992. Reactions of a calving glacier to large changes in water level. Anm. Glaciol., 16, 158-162.

Lliboutry, L. 1956. Nieves y glaciares de Chile: fundamentos de glaciologia. Santiago, Ediciónes de la Universidad de Chile.

Malagnino, E. and J. Strelin. 1992. Variations of Upsala Glacier in southern Patagonia since the late Holocene to the present. In Naruse, R. and M. Aniya, eds. Glaciological researches in Patagonia, 1990. Nagoya, Japanese Society of Snow and Ice, 61-85.

Marangunić, C. 1964. Observaciones glaciológicas y geológicas en la zona del Paso de los Cuatro Glaciares, Hielo Patagónico Sur. Ph.D. thesis, Universidad de Chile.

Meier, M. F. 1994. Columbia Glacier during rapid retreat: interactions between glacier flow and iceberg calving dynamics. In Reeh, N., ed. Workshop on the Calving Rate of West Greenland Glaciers in Response to Climate Change, Copenhagen. Sept. 13 15, 1993. Copenhagen, Danish Polar Center, 63-84.

Meier, M. F. and A. Post. 1987. Fast tidewater glaciers. J. Geophys. Res., 92 B9), $9051-9058$.

Meier, M. F., L. A. Rasmussen, R. M. Krimmel, R. W. Olsen and D. Frank. 1985. Photogrammetric determination of surface altitude, terminus position, and ice velocity of Columbia Glacier, Alaska. U.S. Geol. Surv. Prof. Pap. 1258-F.

Mercer, J. H. 1965. Glacier variations in southern Patagonia. Geogr. Rev. $553), 390-413$.

Powell, R. D. 1980. Holocene glacimarine sediment deposition by tidewater glaciers in Glacier Bay, Alaska. (Ph.D. thesis, Ohio State University.)

Powell, R. D. and B. F. Molnia. 1989. Glacimarine sedimentary processes, facies and morphology of the south-southeast Alaska Shelf and fjords. Mar. Geol., 85, 359-390.

Qamar, A. 1988. Calving icebergs: a source of low-frequency seismic signal from Columbia Glacier, Alaska. 7. Geophys. Res., 93 B6), 6615-6623.

Syvitski, J.P.M. 1989. On the deposition of sediment within glacierinfluenced fjords: oceanographic controls. Mar. Geol., 85, 301-329.

Warren, C.R. 1991. Terminal environment, topographic control and fluctuations of West Greenland glaciers. Boreas, 20 1), 1-15.

Warren, C. R. 1992. Iceberg calving and the glacio-climatic record. Prog. Pliys. Geogr., 16 (3), 253282.

Warren, C. R. 1994. Freshwater calving and anomalous glacier oscillations: recent behaviour of Moreno and Ameghino glaciers, Patagonia. Holocene, $4(4), 422-429$.

Warren, C.R. and D.E. Sugden. 1993. The Patagonian icefields: a glaciological review. Arct. Alp. Res., 25 (4), 316-331.

Warren. C. R., N. F. Glasser, S. Harrison, V. Winchester, A. R. Kerr and A. Rivera. 1995. Characteristics of tide-water calving at Glaciar San Rafael, Chile. J. Glaciol., 41 (138) (in press). 